\title{
Lean organization: a new direction for ports in global logistics
}

\author{
Eon-Seong Lee ${ }^{*}$ and Dong-Wook Song ${ }^{* *}$
}

\begin{abstract}
A port plays a crucial role in total logistics chain by conducting its function as a gateway for inbound (import) and outbound (export) cargo operations. The port has traditionally been regarded as a connecting place where handles ships on one side and cargoes on the other side. These interactive functions to be carried out by the port imply that a port organization should be established, maintained and altered in a way that generates a value-adding activity to the whole logistics chain. This paper aims to suggest an alternative direction for a port organization in context of changing global logistics environment so as to be better prepared for the ever-changing business horizon. Such an attempt will provide global logistics and port management with a strategic insight into innovative and responsive port organizational strategies.
\end{abstract}

Keywords: lean organization, port, global logistics, organizational learning, conceptual application.

\section{Introduction}

As international trade has been significantly increased and customers are demanding greater value of products and services, managers' interest in global logistics and supply chains are growing. Well planned and executed logistics and supply chain management has been identified as a means to provide the organization with a sustainable competitive advantage. Transport is an integral part of the entire supply chain, and a port plays an important role by providing efficient infrastructures

* Researcher in Maritime Logistics, Logistics Research Centre, Heriot-Watt University, Edinburgh, EH14 4AS, United Kingdom; Tel: +44 131451 8003; Fax: +44 1314513 498; E-mail: es12@hw.ac.uk

** Corresponding Author, Reader in Maritime Logistics, Logistics Research Centre, Heriot-Watt University, Edinburgh, EH14 4AS, United Kingdom; Tel: +44 131451 8206; Fax:+44 131451 3498; Email: D.Song@hw.ac. uk 
and inland connections. In this respect, the port is a crucial part of logistics (Carbone and Martino, 2003). The strategic importance of port operators is to provide value to a number of customers engaged in global logistics and supply chain management. This argument implies that a port organization should be established, maintained and altered in a way that generates a value-adding activity to the whole logistics chain. With the aforementioned in mind, this paper aims to conceptually suggest a new alternative for port organization in context of ever-changing global logistics environment so as to be better equipped for the new face of business horizon. Such an attempt will provide global logistics and port management with a strategic insight into innovative and responsive port organizational strategies.

As per the aforementioned objective, the argument of this paper will be based on both an evolutionary theory and an organizational learning theory in order to explain the way of how port organizations change. The evolutionary theory focuses on organizational change process through a continuous cycle of variation, selection and retention. These changing processes can be then further vindicated through organizational learning. Organizational changing processes associated with ports will be discussed in this theoretical context in accordance with global logistics management.

When it comes to the direction of port organizational changes, a lean concept will be introduced for port's value-adding role in global logistics chain. Leanness has been well received in operations management literature since it emphasizes waste removal, quick responses to customer demands, and continuous improvement in manufacture as well as service sectors. Therefore, the lean system would support an efficient and effective operation of the port industry - this new operational and organizational direct is named herein as 'lean port organization'.

This paper is structured as follows. A brief review on current port business environments in global logistics and on the necessity for port organizational change is made in section 1. Section 2 is dedicated to a theoretical background of organizational changes, and the lean concept is discussed in the following section. With a conceptual framework, detailed arguments for the lean port organizational change will be presented in section 4 . Summary and strategic implications for port and global logistics management will be presented in section 5 , followed by conclusions.

\section{Ports in global logistics and supply chain}

Time-based competition has become a critical management issue (Christopher, 2005). Delivering products to customers in the right time, at the right place and at the right price has become a new challenge, rather than producing only high quality products. Global logistics and supply chain management approach has thus been increasingly identified by many organizations as an opportunity to achieve these goals (Chin, Tummala, Leung and Tang, 2004).

In general, logistics refers to the flow of materials from suppliers to an organization. It also refers to those operations within the organization and the distributive processes to customers (Panayides, 2006). Logistics is comprised of all the operations needed to deliver goods or services, except making the goods or performing the services. It covers the material flows between plants and between production lines within a plant. It also includes the information flows generated by the 
processing of transactions associated with the material flows, as well as flows of the funds triggered by the movements of goods and information (Baudin, 2004). Christopher (2005) suggests that logistics be essentially in a planning orientation framework that seeks to create a single plan for the flow of products and information through a business. Caputo and Mininno (1996) define logistics as physical and information flows from a producer to a final consumer. In order to guarantee these flows, several activities have to be carried out inside the channel in a coordinated way. Stock, Gresis and Kasarda (1999) explain that logistics is the process of planning, implementing and controlling the efficient flow and storage of goods, services and related information as they travel from a point of origin to a point of consumption. Some of the activities that are included in the logistics domain include transportation, warehousing, purchasing and distribution. Overall, the existing literature highlights the common characteristics of the logistics as all the activities for the flow of product and information from a producer to a final consumer.

Moreover, supply chain consists of a series of activities and organizations that raw materials and information move through on their journey from initial suppliers to final customers (Panayides, 2006). Again, Christopher (1998) defines the supply chain as a network of organizations that are involved, through upstream and downstream linkages. Panayides (2006) further clarifies that supply chain management involves the integration of all key business operations across the supply chain.

Comparatively, logistics management is primarily concerned with optimizing flows within the organization, whilst supply chain management extends the boundary of internal integration by itself (Christopher, 2005). While the locus of logistics control has been the individual firm (Stock, Gresis and Kasarda, 1999), supply chain management has expanded the concept of logistics to include multiple tiers of suppliers, customers and distributors (Taimoto, 2000; Christopher, 1998; 2005). Thus supply chain management is a broader concept than logistics.

Moving on to a step further, global logistics and supply chain management becomes a fundamental function to the improvement of an organizations' performance, as well as the performance of those entities on the supply chain. Improvements can be achieved by reducing or eliminating the buffers of inventory that exist between organizations in a chain. It can be done through the sharing of information on demand and current stock levels.

Today a port being a node of transportation plays a substantial role in management and coordination of materials and information flows, as transport itself is an integral part of the entire supply chain. Accordingly the expectation from port services is greatly increasing. In order to become as a logistics platform, the port has to simultaneously work in several directions having taken into account those expectation and requirements from the providers and receivers of goods. Physical accessibility from land and systematic organization of information flows would be decisive factors when choosing a port. In this respect, the port is an organization in which a number of logistics and transport operators or stakeholders are involved in bringing value to consumers. This value can be created when a port operator goes beyond the mere transportation function of services to ships and cargoes (Carbone and Martino, 2003). The value of a port can be herein defined as differentiated services on the basis of customer's requirements. Therefore, the role of ports can be summarized in the following two ways - firstly, a port can add value to a logistics and supply chain through the availability of efficient infrastructures and inland connections; secondly, a 
port can contribute to the value creation by accomplishing qualitative attributes through providing reliability, punctuality, frequency, availability of information and security.

Large portion of literature has attempted to specify the importance of ports in global logistics and supply chain management. The existing works have can be categorized into four as indicated in Table 1 - firstly, their emphasis on the port's role in logistics and supply chain integration (e.g., Carbone and Martino, 2003; Panayides, 2005), secondly, on strategic directions and implications for port managers to respond to changing business environments (e.g., Notteboom and Winkelmans, 2001; Song, 2003), thirdly, on changing ports' value adding role (e.g., Robinson, 2002) and introducing lean and agile concepts to a port (e.g., Paixao and Marlow, 2003), and finally, on development of new performance measurement framework in line with the changing business pattern (e.g., Bichou and Gray, 2004; Marlow and Paixao, 2004).

Table 1

Port studies in a new environment

\begin{tabular}{|c|c|c|}
\hline Category & Main Points & References \\
\hline $\begin{array}{c}\text { Ports in logistics and } \\
\text { supply chain integration }\end{array}$ & $\begin{array}{l}\text { - Analyzing a port's role facing the challe } \\
\text { nge of a higher integration of the supply } \\
\text { chain through the field study of the port } \\
\text { of Le Havre in Renault's supply chain } \\
\text { - Evaluating integration of ports and termin } \\
\text { als in global supply chain systems }\end{array}$ & $\begin{array}{l}\text { Carbone and Martino } \\
\qquad(2003) \\
\text { Panayides (2005) }\end{array}$ \\
\hline $\begin{array}{l}\text { Strategic direction } \\
\text { of a port }\end{array}$ & $\begin{array}{l}\text { - Examining the impact of structural chang } \\
\text { es in international trade transport and shi } \\
\text { pping on strategy and operation of ports } \\
\text { - Proposing a new strategic option, co-opet } \\
\text { ition for the port industry to cope with c } \\
\text { hanging business environment }\end{array}$ & $\begin{array}{c}\text { Notteboom and } \\
\text { Winkelmans (2001) }\end{array}$ \\
\hline Changing role of a port & $\begin{array}{l}\text { - Presenting value adding role of a port in } \\
\text { global logistics system } \\
\text { - Introducing lean and agile concepts to a } \\
\text { port to respond dynamic its environment }\end{array}$ & $\begin{array}{l}\text { Robinson (2002) } \\
\text { Paixao and Marlow } \\
\qquad(2003)\end{array}$ \\
\hline $\begin{array}{l}\text { Port performance } \\
\text { measurement }\end{array}$ & $\begin{array}{l}\text { - Proposing a framework for port performa } \\
\text { nce from a logistics and supply chain } \mathrm{m} \\
\text { anagement aspect } \\
\text { - Proposing the measurement of lean ports } \\
\text { performance }\end{array}$ & $\begin{array}{c}\text { Marlow and Paixao } \\
\text { (2004) }\end{array}$ \\
\hline
\end{tabular}

Source: Compiled by the authors

These studies have made a contribution to better understanding of the port's crucial and 
changing role in the newly created business circumstance of global logistics and supply chain management. However, there are few studies from which we could draw a coherent and prescriptive conclusion - in other words, an elaborative remark on how a port plays a value-adding role has yet been made.

An argument is made that ports meet the new challenges and undergo some organizational innovation processes in order to cope with their dynamic and uncertain business environments. For example, Paiaxo and Marlow (2003) introduce the lean and agile concept as a new direction for ports; however, their claim does not lead to a pragmatic or easily applicable framework stemmed from the empirical observation. As a potential extension of their study, the current paper intends to examine a specific option that enables port organizations to play a valuable role in the new era of global logistics and supply chain and a way of how to change the port organization to better perform this new function.

\section{Theoretical issues on organization}

To understand how organizations change, a number of studies have borrowed concepts, metaphors, and theories from other disciplines. For example, Van de Ven and Poole (1995) introduce four basic theories that serve as building blocks for explaining processes of change in organizations. These include life cycle, teleology, dialectics and evolution theories. They classify these four types according to a unit and mode of organizational changes. In particular, an evolutionary theory is embraced in multiple entities of a unit of analysis and prescribed mode of change. Chandler (1992) provides how the evolutionary theory of the firm offers an understanding of the process by explaining that firms respond to moves by competitors, and adjust to the constantly changing economic, social and political environment through organizational learning and changes of the organizational routines. In his study, organizational learning and capabilities are emphasized as a factor for a firm's competence. In addition, Nelson and Winter (1982) suggest that evolutionary viewpoint can be used as a possible framework for a firm and industry behaviour as it can prescribe an organizational changing process in a systematic way. Based on the framework developed by Nelson and Winter (1982), this paper will discuss port organizational changes. Their view can systematically explain port organization's dynamic change process and a desirable direction for this change.

\subsection{Evolutionary theory}

Evolutionary theory focuses on cumulative changes of populations of organizational entities. The theory is used widely by economists to describe how the structure of an economy changes over time (Nelson, 1995). An evolutionary model can be illustrated, as in Figure 1, by the processes of variation, selection, and retention among numerous organizational entities, which is characterized as a recurrent, cumulative and probabilistic progression (Nelson and Winter, 1982; Van de Ven and Poole, 1995). 
Variation is about the creation of novel forms of organizations, which are often viewed to emerge by blind or random chance (Van de Ven and Poole, 1995). Variation comes about as the result of some individuals or small groups trying to get their organization to engage in activities that are outside of the scope of its current activities. They often derive from new combinations of individual and organizational skills and capabilities that are quite often triggered by ideas or events external to the organization. For example, variation in strategic initiatives can be derived from the individual strategists seeking expression of their special skills and career advancement through the pursuit of different types of strategic initiatives. In some cases, operational-level managers can seek to use their skills in new combinations with the organization's distinctive competences and career advancement through alternative opportunity structures (Burgelman, 1991).

\section{The Evolution Process}

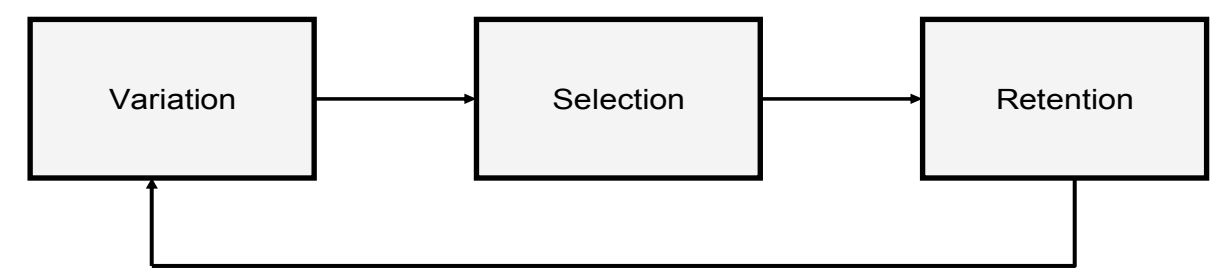

Source: Drawn from Van de Ven and Poole (1995, p. 520)

Figure 1. The evolution process

Selection of an organization occurs principally through the competition for scarce resources, and the organization selects entities that best fit the resource base of an environmental niche (Van de Ven and Poole, 1995). Selection works through administrative and cultural mechanisms regulating the allocation of attention and resources to different and distinctive competences. This process is embodied in various ways-organizational goal definitions, domain delineation, and shared views of organizational character. For example, the strategic context selection processes allow autonomous initiatives to be internally evaluated and selected outside the regular structural context by a top management team. Consequently, it may lead to a change in the organization's 
strategy. Such amendments, in turn, are integrated into the new business activities. Selection process requires much iteration and substantive interaction between managers from different levels in the organization. As the process unfolds, and more information becomes available, top management is able to evaluate the adaptive potential of the new activities for the organization (Burgelman, 1991).

Retention involves forces that perpetuate and maintain certain organizational forms. Retention serves to counteract the reinforcing loop between variations and selection (Van de Ven and Poole, 1995). For example, changes in organizational learning, distinctive competence, and relative importance of new activities in total domain activity may lead top management to recognize that a major change in an organizational activity is necessary and feasible. Once formally ratified, this new vision becomes part of the basis for the induced process (Burgelman, 1991).

Considering the entities of the evolutionary change model, Nelson (1995) notes individuals and organizations as entities that search and learn. More specifically, to determine "what individuals or organizations do", Winter and Nelson (1982) have used the term "organizational routines". Nelson and Winter (1982) define the organization as a set of interdependent operational and administrative routines which slowly evolve on the basis of performance feedbacks and regard routines as units of analysis of evolutionary theory. Organizational routines are also viewed as temporal structures that are often used as a way of accomplishing organizational work (Feldman, 2000). Routines include the forms, rules, procedures, conventions, strategies, and technologies around which organizations are constructed and through which they operate. They also include the structure of beliefs, frameworks, paradigms, codes, cultures, and knowledge that buttress, elaborate, and contradict the formal routines (Levitt and March, 1988). Routines are the product of processes that involve profit-oriented learning and selection (Nelson, 1995). Effective operating routines are always necessary behaviours and superior operating routines are always a source of advantage (Gavetti and Levinthal, 2000).

Routines can be regarded as the result of an organizational learning process (Nelson, 1995). In general, the literature suggests that routines are the outcome of trial and error learning and the selection and retention of past behaviours (Gavetti and Levinthal, 2000). Routines are transformed at the same time as the organization learns alternative routines affected by their transformations (Burgelman, 1991). The relationship of the routines, organizational learning and the evolutionary theory can illustrated in Figure 2. In considering the organization change process from the evolutionary framework of variation, selection and retention, the entities of change is routines, and the change is processed through organizational learning (Baum and Singh, 1994). The existing routines of an organization can be changed into or replaced by new routines to respond competitive environment. This change could be performed by organizational learning. The relation between evolutionary process and organizational learning will be discussed in the next section. 


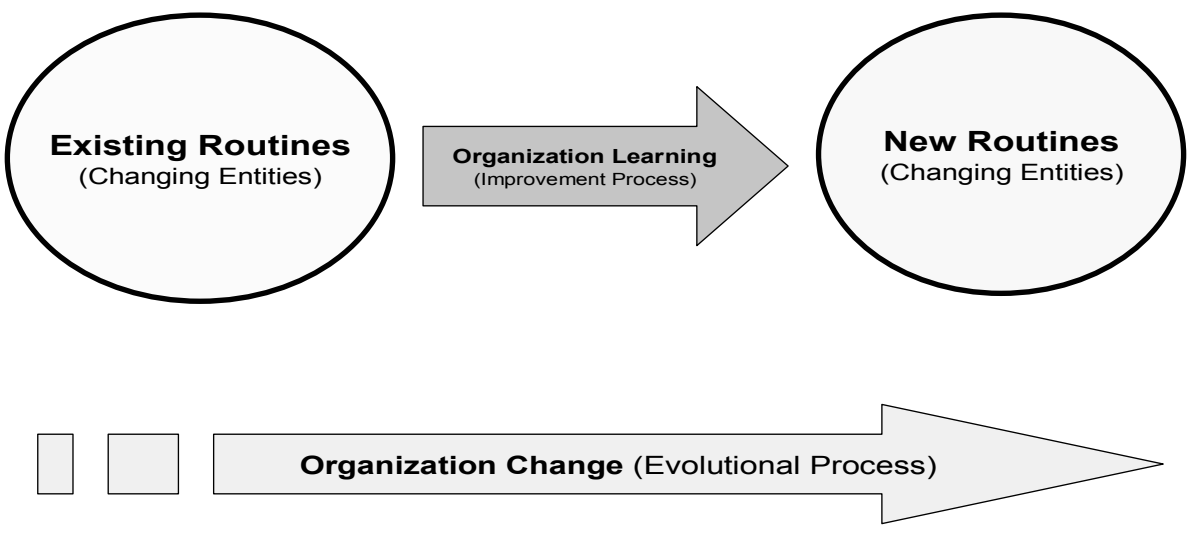

Figure 2. Routines and organizational learning

\subsection{Evolutionary process and organizational learning}

Organizational learning has been emphasized as a crucial source of firms' competitive advantage in the field of strategy and organization studies (DeGeus, 1988; Stata, 1989), and many studies have attempted to generalize its common framework. However, convergence has not occurred because different researchers have applied the concept of organizational learning to different domains. Crossan, Lane and White (1999) developed a framework outlining the process of organizational learning; presenting organizational learning as four processes: intuiting, interpreting, integrating, and institutionalizing. Intuiting is a process of individual level learning by focusing on the subconscious process of developing insights. Interpreting involves picking up on the conscious elements of the individual learning process. Integrating relates to the process of collective and coherent action from group level learning. Finally, institutionalizing is a routine and structured memory process as a result of organizational learning.

From the perspective of evolutionary theory, organizational learning can be understood as the process of organization change (Baum and Singh, 1994). Organizations are transformed and developed through organizational learning. Zollo and Winter (2002) suggest a general framework linking organizational learning mechanisms to the evolution of operating routines. They provide an evolution of organization routine by using the evolutionary paradigm of variation-selectionretention and organization learning process. Zollo and Winter's (2002) study has contributed to suggest the systematic framework of organizational learning and evolutionary process. This study adopts their framework to explain organization change in ports. Their study focuses on the 
knowledge evolution cycle - knowledge articulation and knowledge codification - to explain the organizational learning process. However, their study excludes the whole organizational learning process because the knowledge transformation process in an organization concentrates on the attribute of organizational knowledge.

This study will extend the framework of Zollo and Winter (2002) by modifying the organizational learning process. As it is articulated the early part of this section, the Crossan et al (1999) framework of organizational learning is appropriate in explaining a port's organizational learning process according to their systematic framework.

Figure 3 combines the evolutionary process and organization learning as elaborated on by Crossan et al. (1999) and Zollo and Winter (2002) to explain organization changes in ports. Intuiting is the preconscious recognition of patterns and possibilities inherent in a personal stream of experience. Interpreting is the explanation, through words and/or actions, of an insight or idea to one's self as well as to others. These two steps are related with the variation stage of the evolutionary process, where individuals or groups generate a set of ideas on how to approach some organizational problems in a novel way or to deal with relatively new challenges. This happens on the basis of a combination of external stimuli (e.g., competitors' initiatives, normative changes and scientific discoveries) with internally generated information or knowledge derived from the organization's existing routines (Zollo and Winter, 2002, p. 343).

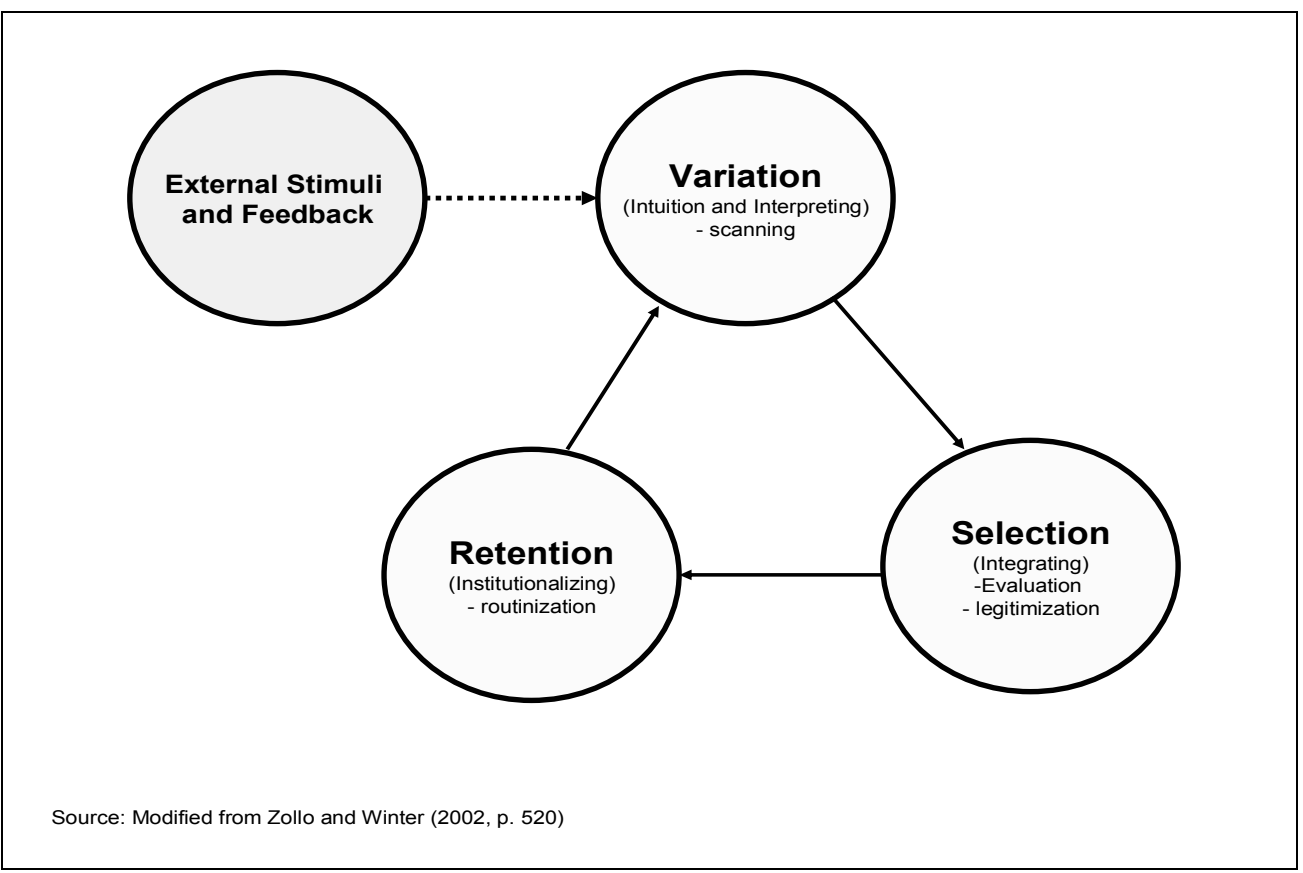

Figure 3. Evolutionary process and organizational learning 
Selecting appropriate systems or changing methods can occur by integrating prior learning. An evaluation of collected information or existing knowledge will affect the selection process. Once a new system is adopted, the organization will implement and replicate the system. Some errors or difficulties may occur when implementing the new system. Retention of the new system will occur through an institutionalizing process after modifying and correcting errors. Finally, new organizational routines will be in place and affect the variation step as feedback.

In summary, the evolutionary process, organizational learning and organizational routines introduced hereto could answer the primary questions of this paper - (i) why the port should be changed and (ii) what process it may be required for such a change. As learning and replicating the new system practices, a port organization could develop the new routine. At this stage, an important question to answer is what system should be selected in a port organization. In other words, the direction of a port organizational change should be suggested.

There may be some alternatives over the direction of a port's organizational change. The most important consideration for port management is to satisfy the demands of the port's customer and improve the whole logistics and supply chain performance. As the evolution in the characteristics of demand regarding the possession of goods brought about by globalization in production, consumption, changing consumer needs and global competition (Panayides, 2006), today's major customers demand and get integrated just-in-time and efficient all-inclusive door-to-door service at a predetermined price (Frankel, 1999). Time-based strategies to reduce inventory costs along the logistics pipeline and to decrease both transit time in ports and lead times are important considerations (Paixao and Marlow, 2004). For this purpose, Marlow and Paixao (2003) discuss the need for ports to be lean in their operations by performing their functions in alignment with market demands while eliminating waste.

These concepts have been applied from logistics literature where pull-systems through determining demand and consequent cost reduction and waste elimination have been practiced for some years (Panayides, 2006). Using lean production theory, a whole range of benefits such as reduced customer lead-times, steady or reducing prices, increased market share, reduced time to launch new services, increased service diversity, productivity and profit can be achieved. The challenge of lean logistics theory for port operators is to move cargo quickly and smoothly through ports, delivering a service in alignment with market demand while eliminating waste (Paiaxo and Marlow, 2004). Extending the above argument, a lean system is selected and legitimated in this study and the details are discussed in the next section.

\subsection{Lean system as a new direction for port organizational changes}

Lean concept was initially introduced by Womack and Jones (1996) to explain Toyota's efficient production system, which aims at reducing waste within the entire operating system. Lean system has been well received in operations management literature, by virtue of the distinguishing features of waste removal, quick responses to customer demands and continuous improvement in manufacture as well as service sectors (Arbós, 2002; Bowen and Youngdahl, 1998; Katayama and Bennett, 1999; Robertson and Jones, 1999). The advantages of the lean system can be realized through eliminating unnecessary processes, aligning processes in a continuous flow and leveraging 
resources in order to solve problems in a continuous process (Sohal, 1996).

Arbós (2002) summarizes two main characteristics of the lean system. Firstly, all activities that do not add value must be eliminated. Those wasteful activities include inappropriate processes, unnecessary carriage and movement, excessive stock resulting in increased cost, quality defects and all manner of delays and times, which would be detrimental with regard to the quality and response. Lean system can improve the operational efficiency by removing wasteful activities. Secondly, lean organizations can respond to customer demands by providing a product or service so that it is faster, more appropriate and less costly. This aspect is covered by flexibility, which means that the system must be attuned at all times to the type and volume of production required by demand (Arbós, 2002). Lewis (2000) also emphasizes that being lean can curtail the firm's ability to achieve long-term flexibility. In order to implement such a lean system, the value stream of an organization should be identified (Womack and Johns, 1996). Womack and Johns (1996) define the value stream as a set of specified actions required to provide a specific product. By identifying the value stream mapping, the administrators can determine processing time including unnecessary time and wasteful resources.

This paper considers the lean system as a new direction for port organizational change from a perspective of both evolutionary theory and organizational learning theory. The conceptual issues are presented in the next section.

\section{Lean port organization}

In the 1950s and 1960s, many nations introduced institutional changes with the aim of coordinating port development at national and regional levels and preventing over-investment in expensive port infrastructure. For example, the United Kingdom established its National Ports Council for this purpose. The privatization wave launched in the late 1970s and early 1980s by Margaret Thatcher, impacted on the port sector and resulted in a re-assessment of the role of the government and private enterprise. Many port managers and government officials believe that the only way to improve the performance of public port organizations was through the process of privatization.

Modernization of port administration has also been an important issue in port management. Modernization of a port assumes that performance can be improved by introducing more suitable systems, working practices, equipment and tools within the existing system of bureaucratic constraints. The advantage of this strategy is that certain changes in the organization can be made without the requirement to change laws or national policy. Examples of this strategy are adoption of corporate planning practices, application of human resources development planning, use of computer applications and management information systems and development of electronic data interchange and information and communication technology. Effort to improve the administrative environment and performance should include the rational use of computer applications and the application of modern communication technologies. Such developments are perhaps the most significant technological efforts undertaken by ports. Some of the global port operators are already 
repositioning their container terminals through joint ventures, port terminals concessions, or implementing green field projects to meet increases in vessel size.

Though ports have experienced serious changes, ports are facing a new force - to change their strategy to cope with dynamically transforming environments. Ports are expected to play a value adding role such as transport consolidation, product mixing and cross-docking activities alongside with their basic operations of cargo handling and storage in a global logistics and supply chain (Paixao and Marlow, 2003). One of the main features required of a port is to be competitive, efficient and flexible. A port organization may require change along these lines, which is the main interest of this study.

As for the said examination, this study will be based on both an evolutionary theory and an organizational learning theory for the explanation of how port organizations change. The evolutionary theory focuses on organizational change process through a continuous cycle of variation, selection and retention. These changing processes can be further explained through organizational learning (Nelson and Winter, 1982). Organizational changing processes related to ports will be described in this theoretical context in accordance with global logistics management.

When it comes to the direction of port organizational changes, the efficiency and flexibility of a port should be an important determinant. Inefficient port operations cause additional inventory costs to the shippers, lower the port capacity and increase operational costs to the transport operators (Marlow and Paixao, 2003). This suggests, therefore, a need for ports to introduce lean system. Lean systems have been widely accepted to improve operational efficiency, reduce total costs and satisfy final customer's needs by reducing wasteful activities and lead-time. A lean system can support the efficient and effective operations of the port industry - this new operational and organizational direct is termed herein as 'lean port organization'. Lean port organization can be defined as a port that follows the lean principle such as operational efficiency by removing waste and flexible responses to customer needs.

Figure 4 shows the main logic of this study. Firstly, port managers and employees can be stimulated by environmental change. They will search for a desirable solution and collect relevant information to respond. Intuiting and interpreting organizational learning process will be performed in this stage. This step is related with the variation stage of the evolutionary process, where individuals or groups are stimulated to seek to use new skills or advancement of organizational routines by external environments or internal organization. Port managers will seek to adopt new systems in new combinations with organization's competences and investigate alternatives when faced with the new challenges. 


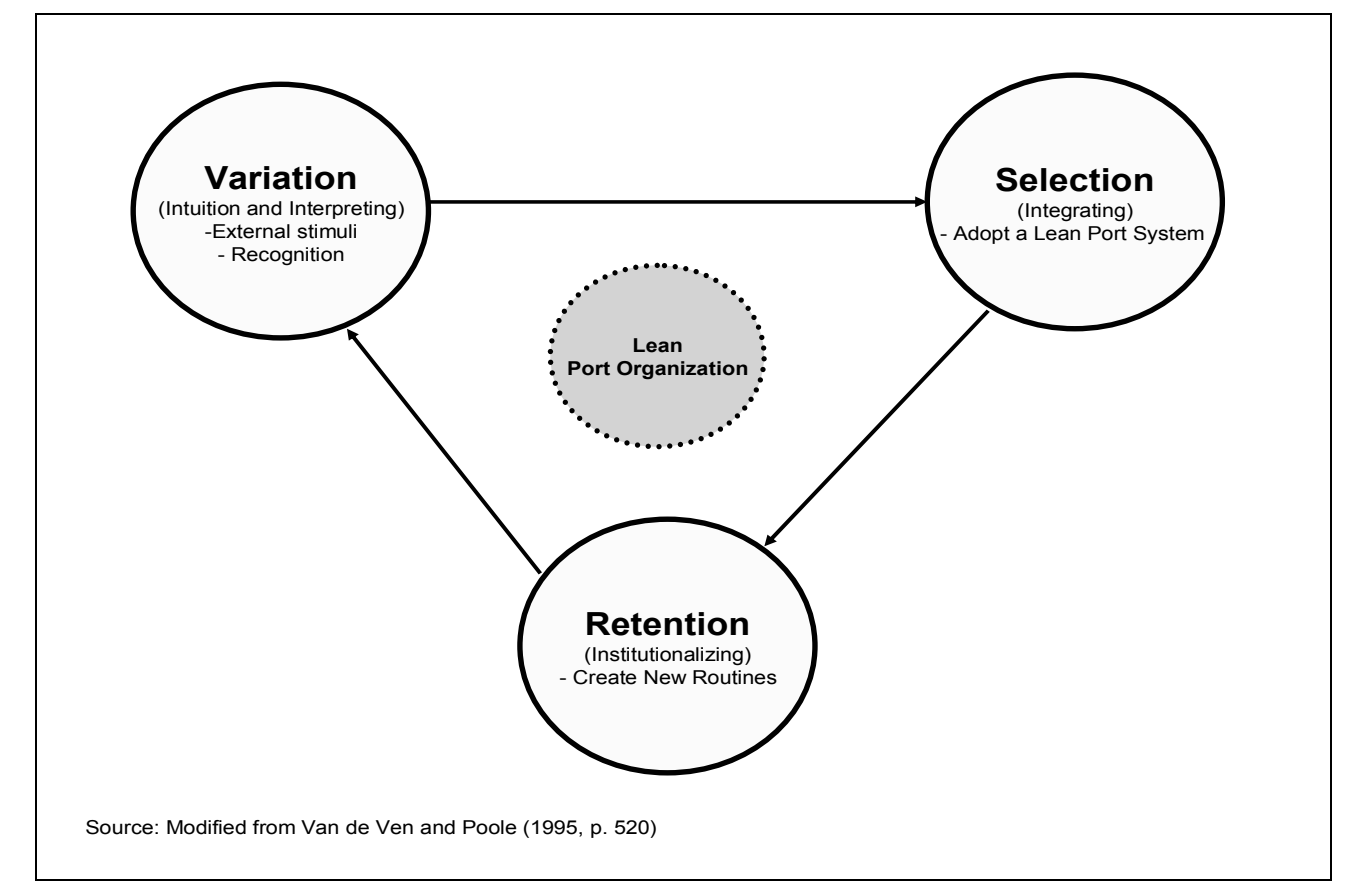

Figure 4. A conceptual framework

Second, selecting alternative methods can occur through an integrating process, where shared understandings among individuals are developed and taking coordinated action through mutual adjustment occurs. This step occurs in the selection stage, where organizations analyze collected information and choose a desirable system according to their own situation. The primary roles of ports are to offer high quality services at a low price and in a timely manner. Lean systems can be used as a solution to respond to external stimuli by providing a port with increased operational efficiency and flexibility.

Third, when adopting a lean system, a port operation should undergo trial and error and identify and correct problems. By implementing this process, a lean port organization can then become newly routinized and institutionalized - the third step of organizational learning, within the retention stage of an evolutionary process.

\section{Discussion and conclusion}

Ports are able to meet the future trends of supply chains insofar as time-based strategies to reduce inventory cost, and to decrease both transit time in ports and lead times. These activities can 
create a greater utility and variety of those services being delivered (Paixo and Marlow, 2003). From the viewpoint of logistics and supply chain management, ports serve as a logistics centres for the flow of cargoes, they link outside flows and develop their own patterns and processes (Bichou and Gray, 2005).

What has become extremely important for ports is cost, efficiency, accessibility, service and reliability in transportation. To realize these advantages, a port should undergo the innovation process, or port organizational change. The aim of this study is to suggest a concept to transform a port organization. For this objective, this study borrows the idea from an evolutionary theory and an organizational learning theory. The evolutionary theory focuses on organizational change process through a continuous cycle of variation, selection and retention. Organizational learning could further explain these changing processes. The 'lean' concept could be pondered for the strategic direction of port organizational changes. The main features of a lean system could be summarized as waste removal, quick responses to customer demands, and continuous improvement in manufacture as well as service sectors. If a port has the characteristics of a lean system, it can be operated efficiently and remain flexible in accordance with its business environments. 'Lean port organization' is suggested as the new operational and organizational direction.

Potential implications for a port and global logistics management can be discussed on the basis of resource based theory. The resource-based theory explains and predicts why some firms are able to establish positions of sustainable competitive advantage, and earn superior returns (Grant, 1996). Competitive advantage originates from firm heterogeneity in resources and capabilities. Firms that are able to accumulate resources and capabilities that are rare, valuable, nonsubstituable, and difficult to imitate will achieve a competitive advantage over competing firms (Barney, 1991). In this respect, a lean port organization can be a source of firm heterogeneity because it can be capable of creating new routines, which is not easy to imitate. Moreover, as those organizational capabilities are intangible resources, they can help lean ports to establish sustainable competitive advantages.

In conclusion, it is claimed that an internally streamlined organisational transformation such as lean organisation should be considered as a serious alternative for mature business sectors. Main container hubs in Asia (e.g., Hong Kong, Singapore and Busan) are respectively faced with their neighbouring ports - for example, Shenzhen ports to Hong Kong, Tanjung Pelepas to Singapore and Shanghai to Busan. In order for them to sustain their competitiveness in the long term, the lean concept suggested in this paper would provide an organisational and strategic insight into why a port should, and how it can, internally undergo an innovative process within global logistics and supply chain, which is the domain for port businesses.

However, this paper has identified an obvious limitation as per its applicability and feasibility to the industry. This constraint would be stemmed from the fact that the concept per se is new to logistics arena, despite it being well recognised in manufacturing sectors, and that port industry is not well exposed to this new concept, thus leading to no real cases to be empirically analysed under this new organisational concept. In a few years time, it is envisaged that port authorities and/or terminal operators would undergo a certain form of internally-oriented organisational reform or restructuring; therefore, the conceptual matters discussed in the paper would be well examined. 


\section{Acknowledgement}

The authors are grateful to two anonymous reviewers for their kind, constructive and valuable comments, which shape the better form of the current paper.

\section{References}

Arbós, L. 2002. Design of a rapid response and high efficiency service by lean production principles: methodology and evaluation of variability of performance. International Journal of Production Economics, 80(2): 169-183.

Alderton, P. 1999. Port management and operations. Lloyds of London Press, London.

Barney, J. 1991. Firm resources and sustained competitive advantage. Journal of Management, 17: 139-157.

Baum, J., and Singh, J. 1994. Evolutionary dynamics of organizations. Oxford University Press. New York.

Baudin, M. 2004. Lean logistics: the nuts and bolts of delivering materials and goods. Productivity Press, New York.

Bawen, D. and W. Youngdahl. 1998. Lean service: in define of a production-line approach, International Journal of Service Industry Management, 9(3): 207-225.

Bichou, K. and R. Gray. 2004. A logistics and supply chain management approach to port performance measurement. Maritime Policy and Management, 31(1): 47-67.

Bichou, K. and R. Gray. 2005. A critical review of conventional terminology for classifying seaports. Transportation Research Part A, 39(1): 47-67.

Burgelman, R. 1991. Intraorganizational ecology of strategy making and organizational adaptation: theory field research. Organization Science, 2(3): 239-262.

Burke, W. 2002. Organization change. Sage Publications, California.

Carbone, V. and M. Martino. 2003. The changing role of ports in supply-chain management: an empirical analysis. Maritime Policy and Management, 30(4): 305-320.

Carputo, M. and V. Mininno. 1996. Internal, vertical and horizontal logistics integration in italian grocery distribution. International Journal of Physical Distribution and Logistics Management, 26(9): 64-90.

Chandler, A. 1992. Organizational capabilities and the economic history of the industrial enterprise. Journal of Economics Perspectives, 6(3): 79-100.

Chin, K., V. Tummala, J. Leung, and X. Tang. 2004. A study on supply chain management practices. Supply Chain Management Practices, 34(6): 505-524.

Christopher, M. 1998. Logistics and supply chain management: strategies for reducing cost and improving service. Financial Times Prentice, London.

Christopher, M. 2005. Logistics and supply chain management: creating value-adding Networks. 
Financial Times Prentice, Hall, New York

Crossan, M. and T. Guatto. 1996. Organizational learning research profile. Journal of Organizational Change Management. 9(1): 107-112.

Crossan, M. and R. White. 1999. An organizational learning framework: from intuition to institution. Academy of Management Journal. 24(3): 522-537.

DeGeus, A. 1988. Planning as learning. Harvard Business Review. 66: 70-74.

Feldman, M. 2000. Organizational routines as a source of continuous change. Organization Science. 11(6): 611-129.

Gavetti, G. and D. Levinthatl. 2000. Looking forward and look backward: cognitive and experiential Search. Administrative Science Quarterly, 45(1): 113-137.

Grant, R. 1996. Toward a knowledge-based theory of the firm. Strategic Management Theory. 17: 109-122.

Katayama, H. and D. Bennett. 1999. Agility, adaptability, and leanness: a comparison of concepts and a study of practice. International Journal of Production Economics. 62(1/2): 4351.

Levitt, B. and J. March. 1988. Organizational learning. Annual Review of Sociology. 14: 190-207.

Lewis, M. A. 2000. Lean production and sustainable competitive advantage. International Journal of Operations and Production Management. 20(8): 959-978.

Marlow, P. and A. Paixao. 2003. Measuring lean ports' performance. International Journal of Transport Management. 1(4): 189-202.

Nelson, R. 1991. Why do firms differ, and how does it matter? Strategic Management Journal. 12(1): 61-74.

Nelson, R. R. 1995. Recent evolutionary the organizing about economic change. Journal of Economic Literature. 33(1): 48-90.

Nelson, R., and S. Winter. 1982. An evolutionary theory of economic change. Cambridge, Mass.: Belknap Press of Harvard University Press.

Notteboom, T. and W. Winkelmans. 2001. Structural change in logistics: how will port authorities face the challenge? Maritime Policy and Management. 28(1): 71-89.

Panayides, P. 2005. Measures for evaluating integration of ports and terminals in global supply chain systems. International Workshop on New Generation Port-Cities and Their Role on Global Supply Chains. University of Hong Kong, December, 12-13 ${ }^{\text {th }}$.

Panayides, P. 2006. Maritime logistics and global supply chains: towards a research agenda. Maritime Economics and Logistics. 8(1): 3-18.

Paixao, A. and P. Marlow. 2003. Fourth generation ports: a question of agility. International Journal of Physical Distribution and Logistics Management. 33(4): 355-376.

Robertson, M. and C. Jones. 1999. Application of lean production and agile manufacturing concepts in a telecommunications environment. International Journal of Agile Management Systems. 1(1): 14-17.

Robinson, R. 2002. Ports as elements in value-driven chain systems: the new paradigm. Maritime Policy and Management. 29(3): 241-255.

Sohal, A. 1996. Developing a lean production organization: an Australian case study. International Journal of Operation and Production Management. 16(2): 91-102. 
Song, D-W. 2003. Port co-opetition in concept and practice. Maritime Policy and Management. 30(1): 29-44.

Stata, R. 1989. Organizational learning: The key to management Innovation. Sloan Management Review. 30(3): 63-74.

Stock, G., N. Gresis, and J. Kasarda. 1999. Logistics, strategy and structure: a conceptual framework. International Journal of Physical Distribution and Logistics. 29(4): 224239.

Taimoto, T. 2000. Theory and Practice of Physical Distribution and Logistics. Hakutoshobo.

Van de Ven, A. and M. Poole. 1995. Explaining development and change in organizations. Academy Management Review. 20(3): 510-540.

Womack, J. and D. Jones. 1996. From lean production to the lean enterprise. Harvard Business Review. 72(2): 93-103.

Zollo, M. and S. Winter. 2002. Deliberate learning and evolution of dynamic capabilities. Organization Science. 13(3): 339-351. 